\title{
MODEL OF COMMUNICATION PLANNING FOR CONTINGENCY PLAN OF DISASTER RISK MANAGEMENT SINABUNG VOLCANO ERUPTION
}

\author{
PUJI LESTARI \\ Universitas Pembangunan Nasional "Veteran" Yogyakarta, Indonesia \\ puji.lestari@upnyk.ac.id \\ EKO TEGUH PARIPURNO \\ Universitas Pembangunan Nasional "Veteran" Yogyakarta, Indonesia \\ paripurno@gmail.com
}

SARI BAHAGIARTI KUSUMAYUDHA

Universitas Pembangunan Nasional "Veteran" Yogyakarta, Indonesia saribk@gmail.com

ARIF RIANTO BUDI NUGROHO

Universitas Pembangunan Nasional "Veteran" Yogyakarta, Indonesia arif.rianto@gmail.com

\begin{abstract}
This study aims to find a communication model of contingency plan for disaster risk management of Sinabung Volcano eruption, in North Sumatera. The object of the research is communication and coordination across the government, non-government organization, and community. This study used planning theory, the concept of communication planning, and types of disaster management plan as tools for analysing. Descriptive qualitative is used as the method. Data collection was obtained from the focus group discussion (FGD), in-depth interviews, observation, and study documentation. There are three stages in descriptive qualitative research that is data reduction, data presentation, and conclusion. An analysis was conducted qualitatively on the program and competence actors. The results found the communication model of disaster risk management through documents of contingency planning to overcome the threat of Mount Sinabung eruption. During the emergency response period a core model was used to reduce the impact of the Mount Sinabung eruption. The contingency plan becomes the Karo District Government's document. This document were authorized by an authorized
\end{abstract}


official and is ready to be applied to the Emergency Response Operation Plan. Plans for emergency response operations are carried out based on information regarding damage and the need to obtain results of a quick review. Contingency plans are submitted to the legislature for political commitment and support and budget allocation.

Keywords: communication model, volcanic eruption, contingency planning, risk management, Sinabung

\section{INTRODUCTION}

Mount Sinabung is located in Karo, one of regency in North Sumatra. In 2010 Sinabung erupted after hundreds of years not happened. During 2011-2012 Mount Sinabung is relatively. However starting in 2013 until July 2017, it has started to go off again. Based on the research of Lestari, Bahagiarti, Paripurno, and Jayadianti (2016: 4265) Sinabung has high disaster risk. The impact of eruption also has not been taken care, as problem refugees and the impact of bodily harm other. Various problems emerge caused by some factors particularly the lack of communication planning and coordination between parties related to disaster management of sinabung itself, such a government, the community, and other private organization.

Communication is the basic element in disaster management as the way of preparedness efforts. Communication needed in the formation of the readiness people in for a disaster, both natural disasters and disaster due to human (Asteria, 2016: 2). Communication disaster mitigation was an act of just a top priority for thought and undertaken to the people who live in proneness. How the government and the parties involved prepare people living in proneness in preparation for disaster by means of information early problems about geology disaster (Roskusumah, 2013:60). Communication involving communicator (sender message) providers, message, channel, communicant (receiver messages), and also the effect of a message. Effective communication based on Indonesia's constitution number 24 
years of 2008 of disaster, preparedness is a series of activities undertaken to anticipate the disaster through organizing as well as through the right steps to take effect. According to the basic law of disaster, the Regional Disaster Management Agency (BPBD) had the responsibility to coordinate through contingency plans. Based on government regulation number 21 years of 2008 on the implementation of the disaster, stated that contingency plan is a process forward planning to the state of being erratic to prevent or remedying a better in an emergency situation or critical with agreed scenario and objectives, set the act of technical and managerial, also a respond and the potential which agreed before.

The research titled Model Communication Planning Based on Contingency Plan For Disaster Risk Management of Sinabung Eruption has been obtained by Lestari, et. all. This research generates a recommendation to decision-makers, both central and local government, disaster experts and the public who are expected to further improve personal communication for the implementation of disaster management as one priority in the national development and it can be realized in a variety of regions in Indonesia. SMS Gateway program and disaster communications SOP can be an alternative for volcano communication model (Lestari et all., 2014: 182). That study has not been effective to reduce disaster risk. This study aims to continue with the focus about planning disaster communication uses planning theory. The study of the planning theory has been carried out by Sawitri (Sawitri, 2004: 15) stated that:

Theoretically and practically, the role of the planner in participatory planning is as a facilitator and communicator who help the communication between participants who produce planning effectively. In carrying out there, instead of relying on knowledge and analysis techniques, planner also needs to have the capacity building dialogue between various parties concerned. In accordance with their role, the planner must uphold ethics brought his behavior to promote public participation and responsibilities to public interests. As a communicator, planner also has to adhere to the pragmatic 
natural norm in communications for obtaining public trust and able to establish communication effectively.

Researchers agreed with Sawitri about the importance of communication for implementing the plan effectively, especially in communication planning for disaster management of Sinabung eruption. In a conceptual manner, communication planning is a commentary on how to disseminate the message whom a right of a communicator to public proper, through proper channels, and also the right time (Wijaya, 2015: 53). The concept of communication planning used as a reference in the process of disaster management plan.

The disaster management consists of five plan as described in Table 1 (Triutomo, 2011: 8-9).

Table 1 Type of Plans in Disaster Management

\begin{tabular}{cll}
\hline No & \multicolumn{1}{c}{ Type of Plans } & \multicolumn{1}{c}{ Principles } \\
\hline 1 & Disaster Management Plan & Arranged in normal conditions \\
& General estimate \\
& Coverage of activities broad / \\
& common covering all stages / the \\
& field of employment disaster be \\
& used for all kinds of natural \\
& disasters ( multi-hazard ) pre on \\
& stage, when emergency, and \\
& after a disaster. \\
& All parties related are involved \\
& Much time available Resources \\
& necessary are still in the \\
& "inventory" step \\
& \\
& Arranged in normal condition \\
& containing about various threats, \\
& vulnerability, resources owned, \\
& organizing and the role of / \\
& function of every single \\
& agencies/ investor \\
bitigation Plan & disasters ( multi-hazard ) \\
&
\end{tabular}


can be used as a guide for the preparation of the sector plans The activities focused on the prevention and mitigation No handle preparedness.

3 Contingency Plan

Arranged before disaster happen The plan is naturally measured Includes specific activities, emphasized on activities to deal with the situation Only can be used for one type of threat(single hazard). the principals who are involved limited based on the type of threat only for a specific period of / any given of the time resources need to the "setup" level.

4 Operational Plan As a continuation or incarnation of the planned contingency, after through fast consideration The plan is very specific Activities are very specific, focused on activities in the emergency step.

Only can be used in one kind of happened disaster the principals who are involved only who really conduct the emergency needs while emergency, (since natural)

5 Recovery Plan Arranged after disaster The nature of the specific plan is according to the characteristic damage the scope of activities are early recovery, rehabilitation, and 


reconstruction
Focusing on any sectors such as
physic, social, and economic
the only parties involved in the
early recovery, rehabilitation,
and reconstruction
need for / long, medium term,
hanging from a large extent the
impact of disasters
resources needed is in stage
application/implementation of
development activities medium-
term/long.

(Source: Triutomo, et.all, 2011; 8-9)

According to a guidebook by Triutomo, et. all (2011: 11), contingency planning is defined as the planning process forward, in a state of erratic, where scenario approved and purposed, the act of managerial and technical determined, and the system to respond to the scene arranged in order to prevent, or overcome a better state or an emergency situation faced by.

Based on the definition, a few grains that important on contingency planning are; 1 ) should be done before in the form of the state of emergency planning process forward, 2) more focusing on the process rather than produce documents, 3) a consensus development process to be agreed scenario and purpose to be taken, 4) a readiness to emergency response by determining step, 5) handling system that will be taken before an emergency occurs and includes efforts and both prevent and also limiting the possibility of consequences that will happen.

Seen from the position in the field disaster, contingency plans are on stage " preparedness," and it is described as Figure 1.

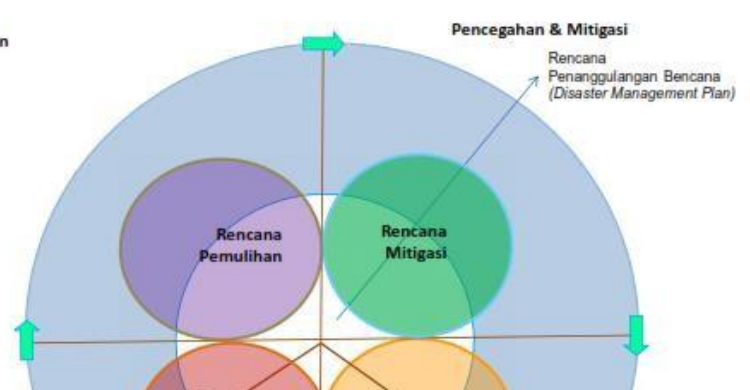


Figure 1: Type of plan in disaster management

(Source: Triutomo, et.all, 2011; 8-9)

Figure 1 can be seen a program contingency plan kind of an early warning in preparedness. The contingency plan is needed to prevent the victim of disaster eruption. To contingency plans, indispensable theory planning, and planning communication.

Based on some number of these studies, this study aims to find a model planning communication to prepare the contingency plan eruption phase of Mount Sinabung in Karo, North Sumatra. Previous research about disaster management was about the understanding Malaysian Malays Communication Characteristics in Reducing Psychological Impact on Flood Victims. The study identifies a more comprehensive list of values related to Malaysian communication characteristics in the context of flood disaster management (Mustaffa, Che Su, et al. (2018).

\section{METHODOLOGY}

This study uses a qualitative approach and wreaks previous research namely disaster communication of Mount Sinabung in Karo district of North Sumatra which erupted in 2010 and 2013 ago. The research was done with descriptive of qualitative methods. This method is used to make the image of the problems regarding the situation or occurrence. According to the Moh Nazir (1985: 64), descriptive study is research that examines the status of a group of humans, an object, a condition that aims to give a picture in systematic, factual and actual concerning the facts, properties as well as the relationship between the phenomenon to be checked. The researcher develops a model of risk management disaster community-based on contingency plan through Mountain Sinabung Karo district of North Sumatra. There are three stages in descriptive qualitative research that is data reduction, data presentation, and conclusion (Hayati, 2015: 351). In the first stage of qualitative 
research is describes the data, second data reduction, and the last researcher performs the data presentation to get conclusions from data that has been prepared and presented. Competence of qualitative researchers, (Hayati, 2015: 356), has a broad and deep insight on the topic to be studied, in addition, researchers are expected to have a sensitivity to see every symptom that exists on the object of research. Researchers have been conducting research on disasters since 2006 during the earthquake in Yogyakarta. Research on disaster communications continues until 2018. In addition, produce scientific publications from previous research results in national journals and international journals.

Primary data collected from the interview with the head of the national disaster agency (BNPB), regional disaster management agency (BPBD). This study has partnered with the BPBD Karo and the Kesbanglinmas of Karo, communities, and stakeholders that involved in the disaster management. This is intended to obtain information on the establishment of a relevant model for risk management. Considering the data and resources disaster management operates in office. Data collection of this research are; in-depth interviews, observation, and study documentation, and Focus Group Discussions (FGD). A reason why this research uses FGD method is because Focus Group Discussions (FGD) is a common approach for data collection in qualitative research projects. The primary characteristic of this method is to use interaction data resulting from discussion among participants. The primary strength of the FGD method is that it can provide rich data, more informative, and valuable insight which can not be discovered through other methods (Afiyanti, 2008: 58).

Focus group discussion (FGD) was conducted by inviting research subject as follows; Element of the plan drafting contingency in Karo (government agency, army/the national police, private institutions, meteorology, climatology and geophysics (BMKG), Indonesian red cross (PMI), Search and Rescue (SAR), Volunteers disaster management, ORARI, NGO, Universities, Business institutions, Mass media, Scout, The 
societies, Youth Organizations, any other parties related to the threat, head of the regional disaster management board (BPBD), NGO representatives, representatives of donors, representatives of volunteers, representatives of disaster victims in Naman Teran, Simpang Empat, Tiganderket, and Payung.

The data collected through FGD included; 1 ) experiences that have been done by the participants in following various programs disaster management of Sinabung 2013, 2) obstacles experienced during involved in disaster management, 3) feedback about disaster management of Sinabung 2013,4$)$ suggestions about model disaster management to disaster mitigation mountain sinabung, 5) material plan drafting contingency to disaster mitigation mountain sinabung: location who is expected to victims, evacuation place, the number and characteristic population, access to get help, long time assistance required, profile refugees, and the total need.

Indonesia uses four volcano alert levels to activate community mitigation plans. In order of increasing criticality, these are Normal, Advisory (Waspada), Watch (Siaga) and Warning (Awas). Implementation of policies, strategies, and actions are tied to each level. In addition, mandatory actions by certain stakeholders are required at certain alert levels. These mandatory actions increase the effectiveness of disaster mitigation by both government and the community. The contingency plan is better if developed in non Warning Stage. (Andreastuti et.all. 2017)

The contingency plan has to be made together by all parties (stakeholders) and multi-sector involved and role in tackling. Including in connection with this were the associated government sector, those state/regions, the private sector, the organization non-government/ NGOs, international organizations and community, and other related parties which still relevant to the type of disaster.

A contingency plan is structured through "processes." This process is essential because it is composed of the participant itself, while the facilitator only directs the process of contingency plans. 
Products from contingency plans are plans, inventories (stockpiles) and budgets, and not emergency response success.

The data collected analyzed by the descriptive qualitative method. First, a whole data presented in data display, then reduced which relevant and which and the main issues examined to later made categorization. The next stage is to make interpretation and the conclusion the results of the study. From the withdrawal conclusion to be obtained a picture of planning model of communications for disaster mitigation mountain Sinabung through a contingency.

\section{RESULTS AND DISCUSSION}

This research finds a model communication planning for disaster risk management plan through contingency of Sinabung and can be applied to the other case of an eruption. Communication plan explain how communicator spread his/her message widely and appropriately through the right channel at the right time. The strategy of communication can be defined as a framework built to change people behavior in wide scale through disseminating new ideas (Wijaya. 2015: 53)

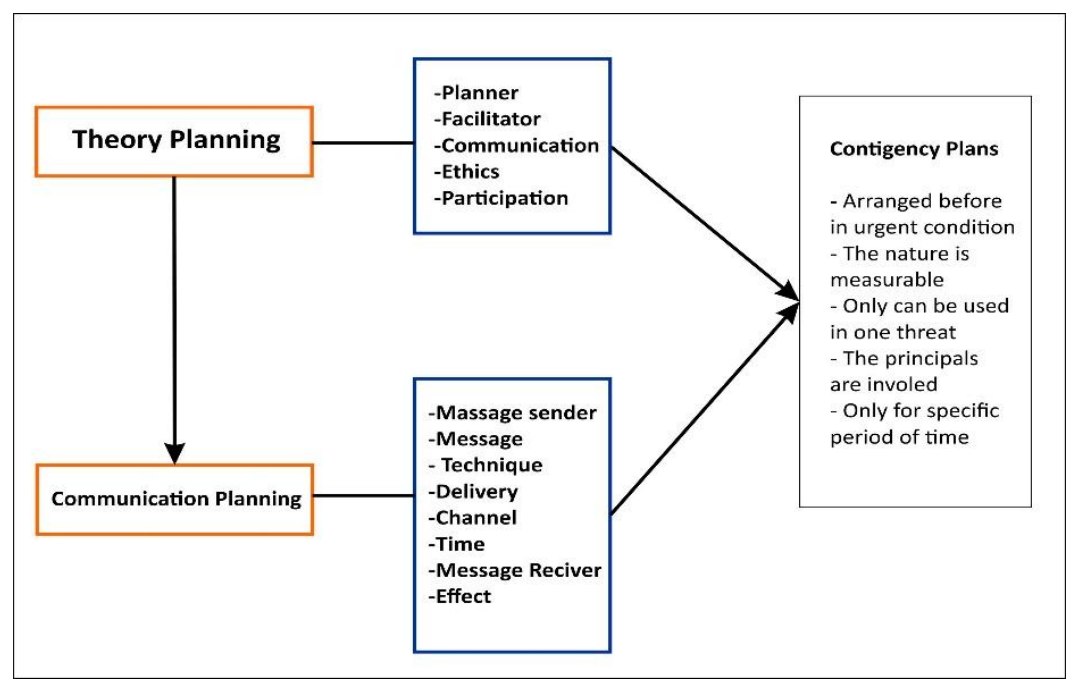


Figure 2: Model planning communication disaster risk management through contigency plan

Figure 2 explain a relation the theory planning, communication planning, and the contingency plan. The method scheme (consisting of the planner, facilitators, communication, ethics, and participation) underlying planning communication (involving messaging, a message, technique delivery of the message, media or channel message, the shipping period and delivery of the message, recipients a message and the impact of messages). The theory planning and communication planning give a guide in making plan disaster management in the form of a contingency plan of Sinabung eruption.

According to the results of interviews with the executive chairman of the BPBD Karo and head of preparedness, the district government Karo especially the regional disaster management board (BPBD) did not have documents contingency plan. In cope with the Sinabung eruption, they use action plan documents or called operation plans. There is no difference between the contingency plan with operation plans, except time of its arrangement. Contingency plan arranged before the disasters so that the plan is based on assumptions and scenario. While operation plans compiled at disaster happen so that the state of reality prepare this plan. Operation plans arranged by adjusting the type of activity and resources are in the contingency plan, based on the real needs of a disastrous kind that has happened.

Based on the information, writers strove to take that information to national disaster agency (BNPB). The results are a contingency plan of Sinabung eruption in 2014. Researchers confirmed to BPBD in Karo District through the executive director, secretary, and head of preparedness for finding the existence of a contingency plan document. The result is they do not understand the document because as the new officers as the result of mutation the officials at BPBD months earlier. Considering that there is a document of contingency plan from BPBD, this research program is updating contingency plan data that has been made by BNPB in 2014. The updating of this data is possible so that the planning can be close to the facts in the field. Data updating is based on 
the contingency plan preparation manual (Triutomo et al., 2011) covering; Activities in the framework of this follow-up plan are listed in the table containing the stages and the actors/sectors as well as the timing of the activities. The process of updating the contingency plan document includes; 1 ) Inventory and maintenance of availability and readiness of resources, facilities, and infrastructure in each area are done periodically, 2) Periodic meetings for review to update data and assumptions of disaster impact or projected resource needs, 3) Developing fixed procedures that can support the implementation/activation of contingency plans that have been prepared, 4) Conduct periodic monitoring of threats and early warning and dissemination. In updating the Contingency Plan document, the researcher performs a data inventory.

\section{Principles of Contingency Planning}

The planning/preparation of a contingency plan has distinctive features that become the principles of contingency planning. By such understanding, contingency plans should be made on the basis of:

- Joint drafting process

- A disaster management plan for single hazard or collateral types.

- Contingency plans have scenarios.

- Shared scenarios and objectives

- Done openly (nothing is covered)

- Assign the roles and tasks of each sector

- Agree with the consensus that has been made together.

- Made for an emergency

In general, the preparation of a contingency plan is carried out in the event of a disaster (the type of threat is known). In this situation, contingency plans are immediately prepared without going through an assessment/analysis of threats/hazards. However, the reality on the 
ground is difficult because the situation is chaotic or panic. It would be better if contingency plans are made when a potential disaster is known.

\section{The period of the contingency plan}

Based on the approximate situation (assumptions) by developing an agreed scenario. Given the dynamics of vulnerability and capacity that very fast, contingency plans need to be adjusted and updated the scenario. In connection with the eruption Plan Plan of the eruption of Mount Sinabung compiled by BNPB 2014, many data are changed. Therefore, it is time to update data. This is done by the research team of UPN Veteran Yogyakarta through the Budget Research Superior University (PUPT) in 2017.

In principle, the preparation of contingency plans other than jointly prepared by all stakeholders also developed scenarios and needs analysis. Once the needs are calculated in detail, it is determined who the executant are, and do not forget to make an assessment (availability) of resources owned by the stakeholders. From the need and availability of these resources, will be known the gap that will be met from various sources prioritizing (potential) local and surrounding resources.

Concerning the Hyogo Framework for Action (HFA Article 4), there has been international recognition of systematic disaster risk reduction efforts integrated into sustainable development and poverty alleviation planning and program policies Disaster Risk Reduction Policy has a goal to improve disaster preparedness and to keep development activities from increasing the vulnerability of communities to disaster threats. Therefore, contingency planning (as well as other types of plans in disaster management) can be established at the community/community level. This is done as an effort to accelerate capacity building at the community level to manage and reduce disaster risk. Due to the large area of Indonesia, it is impossible for the Government to handle itself. Therefore, community empowerment is needed by building the capacity of people in disaster-prone areas that 
are at high risk, for them to be resilient to disaster. People are the first to deal with disaster risks so they must be able to cope.

\section{The involved component}

The response of disaster mitigation agencies and communities to anticipate disaster depends on a common understanding of the hazards and an ability to take action during the event. Differences in hazard perception among emergency managers and scientists can lead to different and sometimes confusing and dangerous response actions. (Andreastuti, et. all 2017).

Scientists can reduce the gap of colective perseption about hazard and disaster. Baser on this condition, contingency plans are prepared jointly by various parties/elements/components of society. This acts intended as an effort of preparedness by all parties since disaster management is a common affair between the government, business institutions, and communities in which the government is ultimately responsible. Each of the parties/actors can play an active role in following the ability, expertise, competence, and authority and contribute/use existing resources within the scope of authority. The element of the plan drafting contingency in Karo are:

- government agency

- army / the national police

- private institutions

- Meteorology, Climatology, and Geophysics (BMKG)

- Search and Rescue (SAR)

- Volunteers disaster management

- ORARI

- NGO

- Universities

- Business institutions

- Mass media

- Scout 
- The societies

- Youth Organizations

- Any other parties related to the threat

\section{Implementation}

Preparation of contingency plans may be undertaken through prior training activities, or through other forums such as coordination meetings, followed by meetings or workshops, or other forms of activities. The formulation of a contingency plan is done through the preparation and implementation.

At the preparation of their activities include the provision of a map districts provincial, data " districts in figures ", data about the supply of resources of the respective sectors/the office's organization/and information from various sources/element that can be accounted for technically.

In the implementation stage, their activities of contingency plan drafting that began in risk assessment, preceded by hazard assessments and determination of the danger to determine one type of a threat or disaster those expected to occur (which became the priority). The process of contingency plan in diagram described in Picture 3.

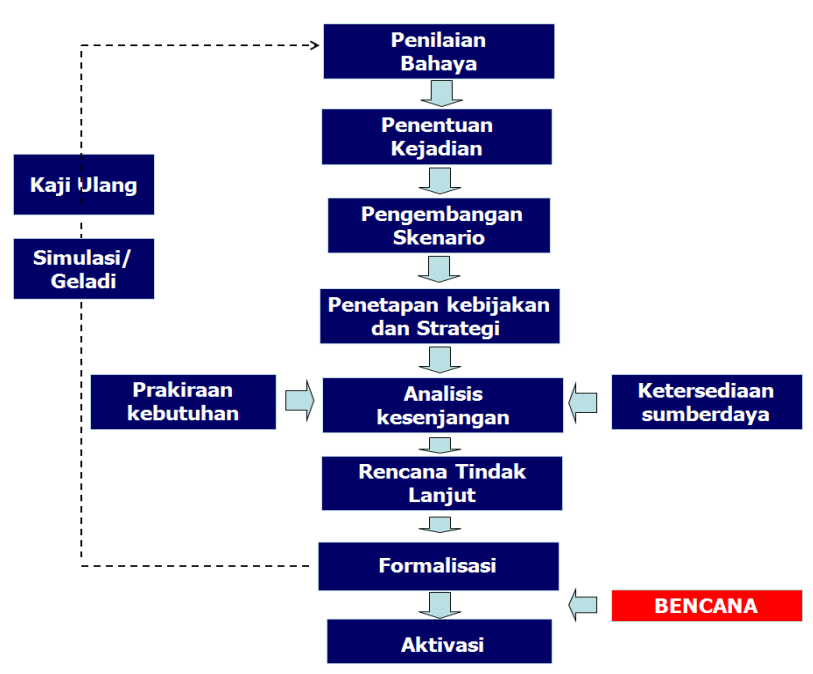

Figure: 3 Diagram contingency plan drafting 
(Source: Triutomo, et.all, 201)

Identification of types of threats and hazard weighting were carried out to assess hazards.

A. Records/ history of disaster were used to identify types of disaster threats. B. Assessment of threats/ hazards from several types of threats in a district/ city one by one.

B. Impact scenarios were developed to explain the assumption of impacts to the community / population by considering local vulnerabilities and capacities affected. This includes public awareness of risks, preparedness and availability of resources in disaster management.

PVMBG instructed residents evacuation within a $10 \mathrm{~km}$ radius of Mount Sinabung. Evacuation is carried out from assembly point to a place of refuge. The transportation used was trucks belonging to citizens and the government. Forty areas were evacuated.

1. Aspect of the population include fatalities, wounded victim, missing victim, evacuated residents as follows:

a. Villages affected within a range of $10 \mathrm{~km}$ were 53 villages, with 57,879 people in total.

b. The number of fatalities were 12 persons, missing victims were 16 persons, evacuated residents as many as 2509 persons, 55,341 displaced people, seriously injured 55 persons, moderate injuries as many as 165 persons, and minor injuries such as 553 persons, and non-care 54,275 persons.

2. Disruption of flights at Kuala Namu Airport Medan due to ash rain.

3. The closure of the road connecting Medan with Berastagi, Kabanjahe and Aceh Province for several hours. Road closure due to evacuation from affected villages, distribution of emergency assistance and disaster relief.

4. Disruption in the learning and teaching process in schools due to the length of eruption and evacuation that is more than 2 months.

5. The livestock sector is affected, including cattle, buffalo, goats, horses and pigs 
Table 2 Impact on the livestock sector

\begin{tabular}{lcccccc}
\hline \multicolumn{1}{c}{ Subdistrict } & Cow & Buffalo & Goat & Horse & Pig & TOTAL \\
\hline Namanteran & 37 & 92 & 301 & 2 & 4 & \\
Simpang Empat & 221 & 6 & 301 & 0 & 58 & \\
Tiganderket & 116 & 21 & 56 & 0 & 87 & \\
Payung & 74 & 2 & 33 & 0 & 0 & \\
Merdeka & 40 & 25 & 70 & 32 & 75 & \\
& 448 & 146 & 761 & 34 & 224 & 1653 \\
\end{tabular}

A. Several villages that were severely impacted and expected to be harvest failures were:

1) Tiganderket sub-district, Tiganderket villages, Mardinding, and Kutambaru, Perbaji, Tigenderket, Temburuh, Sukatendel.

2) Namanteran sub-district, Kutarayat villages, Simacem, and Bakerah, for all commodities.

3) Merdeka sub-district, Ujungtera Village, Deram, Sadagperurih, Cintarayut.

B. In the areas left by residents/farmers due to evacuate, it is estimated that the plants will be damaged, in:

1) Payung sub-district, the villages of Guru Kinayan, Sukameriah, Payun, Sukadi, Umbrella End, Cimbung, Bahekarang, Rinokaro.

2) Tiganderket Sub-district, Mardingding Village.

3) Teran Sub-district, Simacem villages, Bakerah, Kuta Gungung

4) Simpang Empat sub-district, village of Beras Sitepu

C. The entire plant area affected by the eruption of Mount Sinabung about $25.735 \mathrm{Ha}$.

1) Vegetables include Leeks, potatoes, cabbage, tomatoes, cauliflower, mustard greens, carrots, celery, lettuce, chili. 
2) Fruits include pineapple, salak, mango, duku, jackfruit, papaya, mangosteen, soursop, avocado.

3) Other commodities include Orange, Coffee, Avocado, Karo Eggplant, Marks.

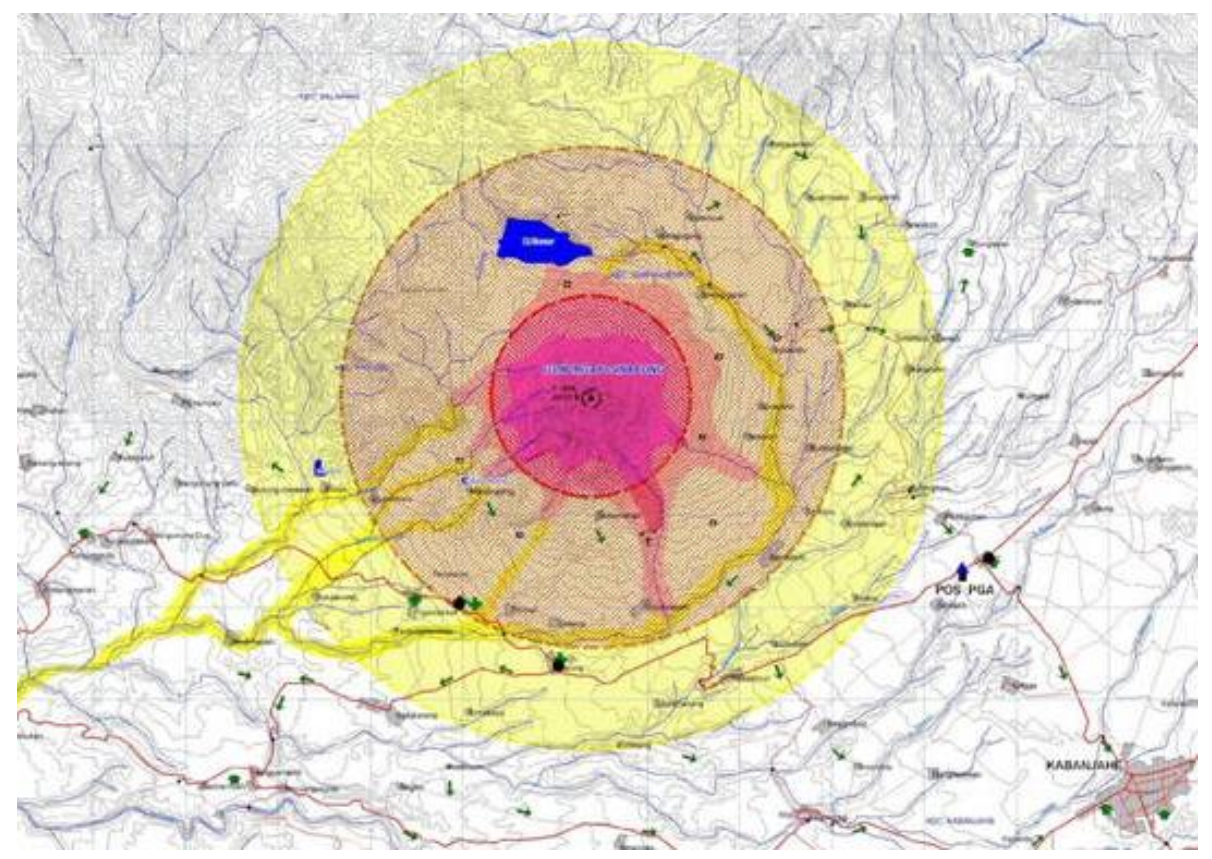

Figure 3: Impacted area of Sinabung Volcano eruption

Source: Pusat Vulkanologi dan Mitigasi Bencana Geologi (PVMBG) 2013

The hazard assessment results are plotted into the Hazard Level Matrix to identify high-risk hazards, as a matrix in Picture 4. 


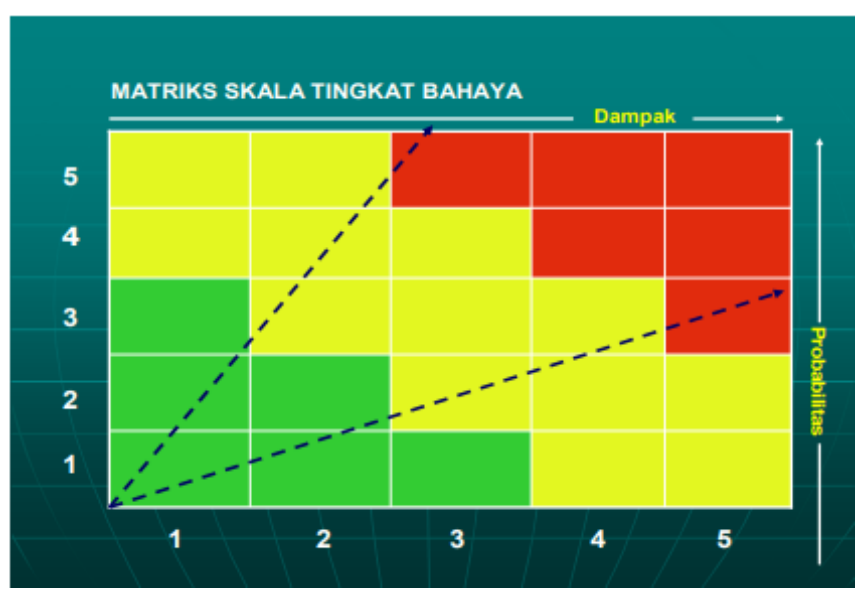

Figure 4. A matrix scale of the danger Source: Triutomo 2011

\section{The determination of occurrences}

From the hazard scale matrix data in Fig. 5, if there are 2 (two) or more threats/hazards occupying the "red" column (the most urgent/dominant or high-risk) that is in the top-six boxes, then disaster risk determination/assessment is done by mutual agreement (crosssector) which is considered the most urgent/priority.

\section{Development of scenario}

Based on region map, can be identified communities and areas/locations that are threatened by disaster (hazard/disaster-prone areas) so that the extent/magnitude of the impact of disasters that may occur. In scenarios can also be described, such as time of disaster (e.g., morning, day, night), duration/duration of events (e.g., 2 hours, 1 day, 7 days, 14 days), high puddles (floods), the height and distance of the waves to the ground (tsunami) and other things that affect the size of the loss/damage.

There are 5 (five) aspects affected by the disaster, i.e., aspects of life/population, facilities/infrastructure/facilities/assets, economy, government, and environment; 1) The impact on aspects of 
life/population can be death, injuries, displacement, disappearance, and others, 2) Impacts on aspects of facilities/infrastructure can be damage to bridges, roads, PAM installations, PLN, damage to homes, and others, 3) The impact on the economic aspects can be damage to traditional markets, crop failures, economic/trade disruptions, transport, and others, 4) Impact on aspects of government can be the destruction of documents/archives, office equipment, government buildings and others, 5) Environmental impacts can include damage to the forest, lake, tourism, pollution, destruction of plantation / agricultural lands, and so on.

To measure the impact on the aspects of life/population, it is necessary to establish pre-estimation of the number of people who are threatened, the impacts of death, injury, displacement, disappearance, and other effects will be determined to determine the number/percentage of impacts. Impacts on aspects of facilities/infrastructure, government, economy, and environment are classified into light, moderate and severe damage.

\section{The Determination of Policy and Strategy}

\section{Policies}

The emergency handling policy is intended to guide the relevant sectors to act/implement emergency response activities. The policy is binding because, in emergency management, there are treaties that must be obeyed by all parties. Examples of policies are (1) determining the time of emergency response to be carried out (e.g., for 14 days), (2) free care/treatment services for disaster victims.

\section{Strategy}

Emergency management strategies are implemented by each sector according to the nature/characteristics of sector tasks. This strategy is aimed at the effectiveness of policy implementation. For example, from the policy of "free care/treatment service for the victim" 
can be formulated strategy "appointing government hospital/private that serves as the referral hospital."

\section{Sectoral Planning}

The first step in sectoral planning is identification activities. All activities for handling urgent thing have to be identified that the problem is tackled and completed, there are no activities that overlap and no vital activities which were left behind. Those responsible for implementation plan drafting contingency joined in the sector (for example management and coordination, evacuation, food and nonfood, health, transportation, infrastructure). About the sector, the number and the nomenclature determined by actors contingency plan drafting. There was no stipulation definite/raw in determining the number of and naming to sectors; 1 ) Sector situation. The situation was an image of the worst condition during the incident, intended to anticipate the level of difficulty in handling emergency and effort to do, 2) Sector target. Intended as goals to achieve in the handling of emergency so that of the community or the victims could have been treated to the full 3) Sector activity. That was conducted during an emergency to ensure that the joined sector could be actively sector. Sector activities triggered by the situation sector during the incident disaster, 4) Sector's actor identification. The emergency management joined in sectors derived from a number of elements good government and non-government, including members of the community broad. 5) Implementation time activities. The implementation time activity by sector is before/ahead of natural disaster, for a moment after of disasters and any when needed.

\section{CONCLUSION}

This study found the communication model of disaster risk management through documents of contingency planning to overcome the threat of Mount Sinabung eruption. The core model is the communication 
planning to reduce the impact of the eruption of Sinabung Volcano, especially during the emergency response. The core of this model is the communication planning in minimizing the impact of the eruption of Mount Sinabung especially during the emergency response in the form of the Contingency Plan document. The contingency plan becomes a document of Karo District Government which is authorized by the authorized official, the Regent of Karo and becomes the official document (regional document) and ready to be implemented into Emergency Response Operation Plan (through the information of damage and the need of the result of the quick review) when disaster strikes. The contingency plan is also submitted to the legislature for political commitment and support and budget allocation. At this stage of the research, the Contingency Plan product has not yet obtained formal approval as the pilot stage, or new postal rehearsal will be conducted in second-year research (2018).

\section{ACKNOWLEDGMENTS}

Our thanks to Research Fund Management And Devotion To The Community (DRPM), The Ministry Of Research Technology And Higher Education (Ristekdikti) 2017, Research Institutes And Devotion Community (LPPM) Universitas Pembangunan Nasional "Veteran" Yogyakarta, all parties involved in preparation of contingency plan eruption Gunungapi Sinabung Especially Regent Karo, Regional Secretary, Assistant Regent, Regional Disaster Management Agency (BPBD) Karo and all head of who attended the Workshop Contingency Plan Karo April 3-4 2017, postal officials observation Mountain Sinabung. Thanks to Dr. Rizaldi Parani S.Sos. MIR for support proofreading this article. 


\section{REFERENCE}

Afiyanti, Yati. (2008). Focus Group Discussion Sebagai Metode Pengumpulan Data Penelitian Kualitatif. Jurnal Keperawatan Indonesia, 12(1), Pp. 58-62. Universitas Indonesia, Jakarta.

Andreastuti, M.Ch.S., Paripurno, E.T., Gunawan, H., Budianto, A, Syahbana, D. (2017). The character of community response to volcanic crises at Sinabung and Kelud volcanoes.

Andreastuti, M.Ch.S., Budianto, A., Paripurno, E.T. (2017). Integrating social and physical perspectives of mitigation policy and practice in Indonesia, in Fearnley, C. J., et al., eds., Observing the Volcano World, Advances in Volcanology, Springer Publications, New York., Asteria, Donna. (2016). Optimalisasi Komunikasi Bencana Di Media Massa Sebagai Pendukung Manajemen Bencana. Jurnal Ikatan Sarjana Komunikasi Indonesia. http://www.jurnal iski.or.id/index.php/jkiski/article/view/30/19)

Hayati, Naila. (2015). Pemilihan Metode Yang Tepat Dalam Penelitian.

Jurnal Tarbiyah al-Awlad, Volume IV, Edisi 1, hlm. 345-357.

Lestari, Puji, Sari Bahagiarti, Eko Teguh Paripurno, Herlina Jayadianti. (2016). Environmental Communication Model For Disaster Mitigation Of Mount Sinabung Eruption Karo Regency Of North Sumatra. Information Journal. International Information Institute. Tokyo. 19 (9B), Pp. 4265-4270. ISSN 1343-4500 elSSN 1344-8994.

Lestari, Puji, et al. (2014). Communication Model for Disaster Risk Reduction with SMS Gateway and a SOP for Early Warning Communications of Mount Sinabung in Indonesia. Conference Proceeding of Sustain The 5th International Conference on Sustainable Future for Human Security Sustain 2014, ISSN: 21880999. http://sustainconference.com/files/procs/Proceeding\%20SustaiN\%202014.pdf)

Mustaffa, Che Su, et al. (2018). Understanding Malaysian Malays Communication Characteristics in Reducing Psychological Impact on Flood Victims. Malaysian Journal of Communication 31(1) http://ejournal.ukm.my/mic/article/view/24424

Sawitri, Dewi. (2006). Profesi Perencana Dalam Perencanaan Partisipatif Suatu Kajian Teori Dan Praktek Perencanaan. Jurnal Mimbar Volume XXII No 1 January-Maret 2006. Universitas Islam Bandung. 
Sugiyono. (2014). Memahami Penelitian Kualitatif. Bandung: Alfabeta. Triutomo, Sugeng, et.el. (2011). Panduan Perencanaan Kontinjensi Menghadapi Bencana. Badan Nasional Penggulangan Bencana. Jakarta.

Republik Indonesia. (2008). Peraturan Pemerintah No. 21 Tahun 2008 tentang Penyelenggaraan Penanggulangan Bencana. Lembaran Negara RI Tahun 2008, No. 4828. Sekretariat Negara. Jakarta.

Republik Indonesia. (2007). Undang-Undang No. 24 Tahun 2007 tentang Penanggulangan Bencana. Lembaran Negara RI Tahun 2007, No. 4723. Sekretariat Negara. Jakarta.

Roskusumah, Titan. (2013). Komunikasi Mitigasi Bencana Oleh Badan Geologi K esdm Di Gunung Api Merapi Prov. D. I. Yogyakarta. Jurnal Kajian Komunikasi. http://jurnal.unpad.ac.id/jkk/article/view/6031 )

Wijaya, Ida Suryani. (2015). Perencanaan dan Strategi Komunikasi dalam kegiatan Pembangunan. Jurnal Lentera Vol XVII No 1 Juni 2015. IAIN Samarinda. hlm. 53.

\section{BIODATA}

Puji Lestari, Associate Professor, Active did research on communication disaster, cross cultural communication, marketing communications, and communication organization. The experience of being head of researchers research grants DP2M of higher education that is grant compete for 2008 until 2018 about disaster communication Mount Merapi and Mount Sinabung, also cross cultural communication ethnic Padang and Java.

Eko Teguh Paripurno, initially renowned as environmentalist through KAPPALA Indonesia organization, in which he established in 1994. He finished his Doctoral degree in Padjajaran University, Bandung. He was awarded an honor of Social Entrepreneur on 2000 from Ashoka Global, and Sasakawa Award from UN-ISDR on 2009, as his efforts in community-based disaster risk management.

Sari Bahagiarti Kusumayudha, active was research about geological research like Geoheritage for Geotourism Development of Karyamukti Village and Surrounding Area, Cianjur Regency, West Java, Indonesia 
(2017) and Fissure structure analysis to unravel groundwater inflow problem in gold mining site of Pongkor area, West Java, Indonesia (2018).

Arif Rianto Budi Nugroho a bachelor's graduate of the Department of Geological Engineering, University of Pembangunan Nasional "Veteran" Yogyakarta acquired his Master in Remote Sensing \& GIS from the Gadjah Mada University and he is currently a doctoral candidate at the Padjadjaran Univesity. He is an active lecturer at Department of Geological Engineering, University of Pembangunan Nasional "Veteran" Yogyakarta. In addition to teaching, he is also an active at Study Center for Disaster Research Education and Management. 